\title{
A SPATIAL ECONOMETRIC ANALYSIS ON THE IMPACT OF COVID-19 ON MORTALITY OUTCOME
}

\author{
Olatunji SHOBANDE ${ }^{1}$, Lawrence OGBEIFUN ${ }^{2}$ \\ ${ }^{1}$ University of Aberdeen, Aberdeen, UK \\ ${ }^{2}$ University of Mississippi, Oxford, USA \\ Corresponding author's e-mail: olatunji.shobande@abdn.ac.uk
}

\begin{abstract}
The study develops and examines the spatial distribution of the Corona Virus Disease (COVID) on mortality outcomes using a global panel dataset of 79 countries. The empirical evidence is based on Fixed Effect (FE) and System Generalized Method of Moment (SGMM) estimator. The predicted variable is proxy with daily mortality outcomes, while the predictor variable is proxy with spatial COVID spread while controlling for social tension and average temperature. The global and regional findings of the study established that spatial variation in COVID spread had positive and significant relationships with mortality outcomes. Further results also indicate that social tension is a contributing factor to the rising daily mortality outcome from the COVD outbreak, whereas temperature variation reduces mortality outcome. Thus, the study recommends the use of statistical modelling to predict and manage the epidemic. Also, there is an urgent demand to deploy essential social need to the vulnerable proportion of the population to reduce the level of social unrest, while strengthening collaborative research among scientists to develop, produce and distribute vaccines that will put an end to the pandemic.
\end{abstract}

Keywords: COVID19, confirmed cases, mortality, System GMM.

JEL Classification: I12; I14; I31

\section{INTRODUCTION}

The daily exponential increase in the novel coronavirus (COVID) disease has continued to decide the fate of both the young and older generation. Various measures have been adopted to contain or delay its spread with little or no impact on the mortality outcomes (Ma et al., 2020; Gautam \& Hen, 2020; Yeo, Kausha, Yeo, 2020). While the virus continued to spread across states, countries and regions of the world, clinical experts and epidemiologists have warned that preparation for the second wave is necessary for the resurgence of the novel coronavirus. The contribution of this study is to describe the spatial distribution of COVID cases and its impact on global population with the hope of providing insight on the pattern of its spread and make an empirical contribution to future public health planning.

According to the World Health Organization, although the novel Corona Virus is characterised by human-to-human transmission, the disease is not considered a severe global pandemic to future population (WHO 2020d). In terms of the risk and 
vulnerability of the disease, COVID has been found to discriminate and varied in mortality outcome across the world. Earlier studies considered COVID to be highly associated with a highly infectious disease that primarily affects the lungs and could lead to acute respiratory illness (Gautam \& Hen, 2020; Yeo, Kausha, Yeo, 2020). It has also shown that patients with existing health issues have a high mortality risk. Recent studies have shown evidence that the pandemic has moved rapidly to inner communities from cities, thereby suggesting that a high mortality outcome is expected in the coming month (WHO, 2020). Given the varied level of preparedness of governments across the world and the sensitively of the population in terms of social awareness, education and sensitisation, the mortality outcome is expected to vary from different countries and regions of the world.

Interestingly, many collaborative strategies have been adopted across the globe ranging from the use of physical, social distancing, contact tracing, awareness on environment cleaning, lockdown, donations and distribution of palliatives to the less privileged proportion of the population. Besides, there has been landmark collaboration in public-private partnership and synergy among international communities such as WHO, UNICEF, World Bank, IMF and European Union (EU) through financial assistance on public health supply, and enlightenment campaigns on the severity of the pandemic. Despite the resounding interventions, the spread of the virus has continued to fester. The problem associated with the fight and the strategies employed in its fight range from temperature variation, coordination failure, social tension, inequality gap, limited funds and unsecured information asymmetry coupled with an infrastructure deficit.

Thus, this study extends the contribution of Adekunle et al. (2020), Shereen et al. (2020), as well as Sarkodie and Owusu (2020) with a departure in a statistical approach and the environment of discourse. The study by Sarkodie and Owusu (2020) focused on China using the dynamic statistics technique, while Adekunle et al. (2020) were motivated to assess the African region. The present study investigates the effect of the spread of the coronavirus on mortality outcomes with a particular focus on the global and regional panel of 79 countries' setting. Also, the study queries whether temperature variation explains the magnitude of the spread of the COVID, which has resulted in the decline in mortality outcomes across the regions of the world. Likewise, our study addresses the gap in the effect of social tension on mortality outcomes.

This study makes three significant contributions to the theoretical and empirical studies on the environmental and health policy. First, the paper develops and applies an econometric model for investigating the role of a spatial pattern in outbreak control in the preservation of population health. Second, it addresses the issue of potential endogeneity using instrumental variable techniques in our estimation and, third, it provides policy strategies tailored toward reducing the spread of the pandemic and prevent future re-occurrence. 


\section{STYLISED FACTS ON SPATIAL SPREAD OF THE CORONAVIRUS PANDEMIC}

The COVID that began in Hubei province, Wuhan-China has moved and spread across the globe extending to more than 187 countries of the world creating social and economic tension on the entire world population (WHO, 2020). Out of the current world population of 7.8 billion, available statistics have indicated that the number of infected cases has risen from 44 confirmed COVID cases reported on 3 January 2020 to 28 million as at 14 September 2020, with a corresponding mortality rate of more than 900000 recorded (WHO, 2020). In terms of the spatial distribution of the COVID diseases across continents, America remains the epicentres of the COVID confirmed cases with (51\%), followed by South East Asia (19\%), Europe (17\%), Eastern Mediterranean (7\%), Africa (4\%), and Western Pacific $(2 \%)$. See the global simulations for death and confirmed cases in Figs. 1 and 2.

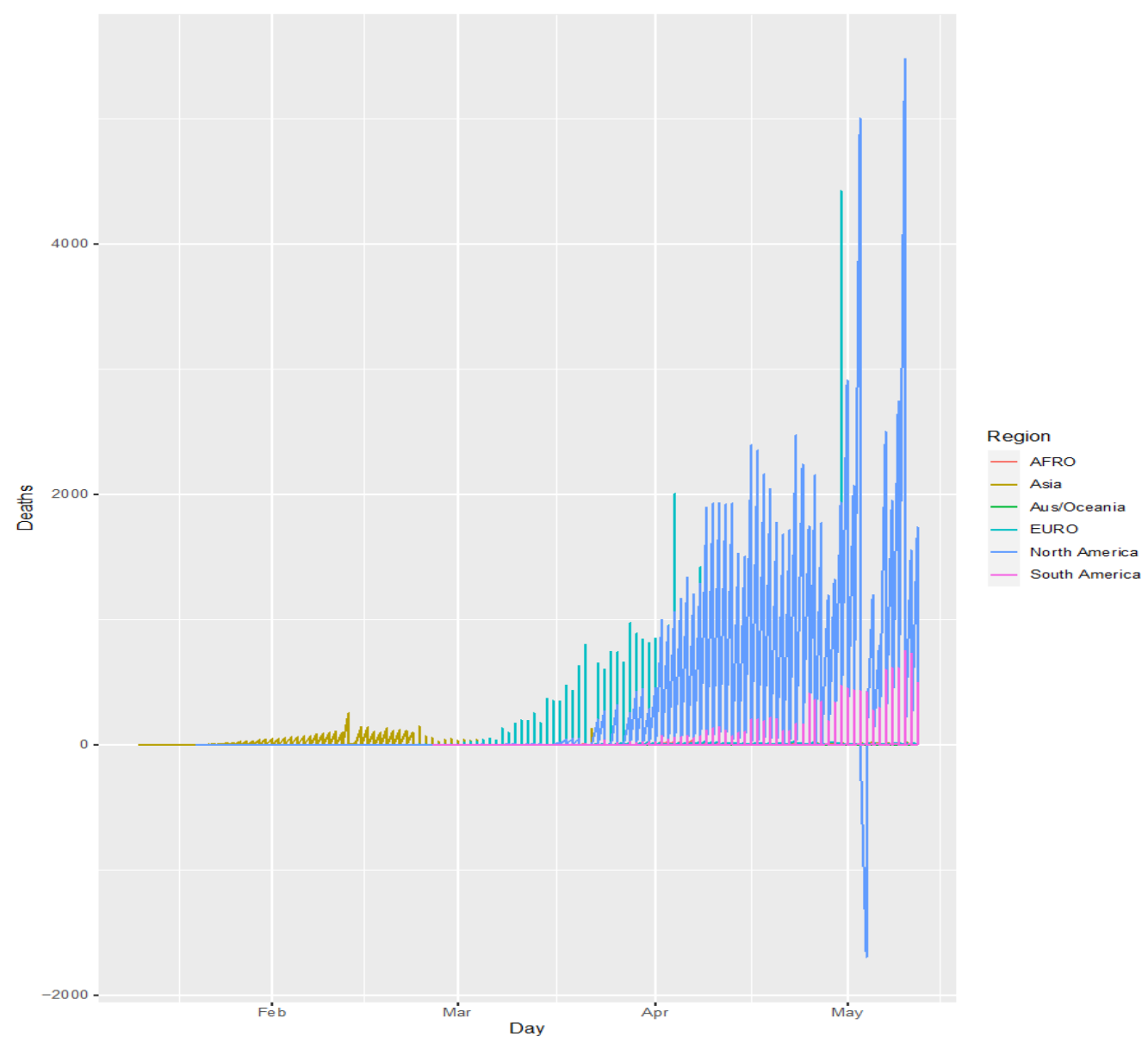

Fig. 1. Global simulation of COVID-19 mortality by region. 


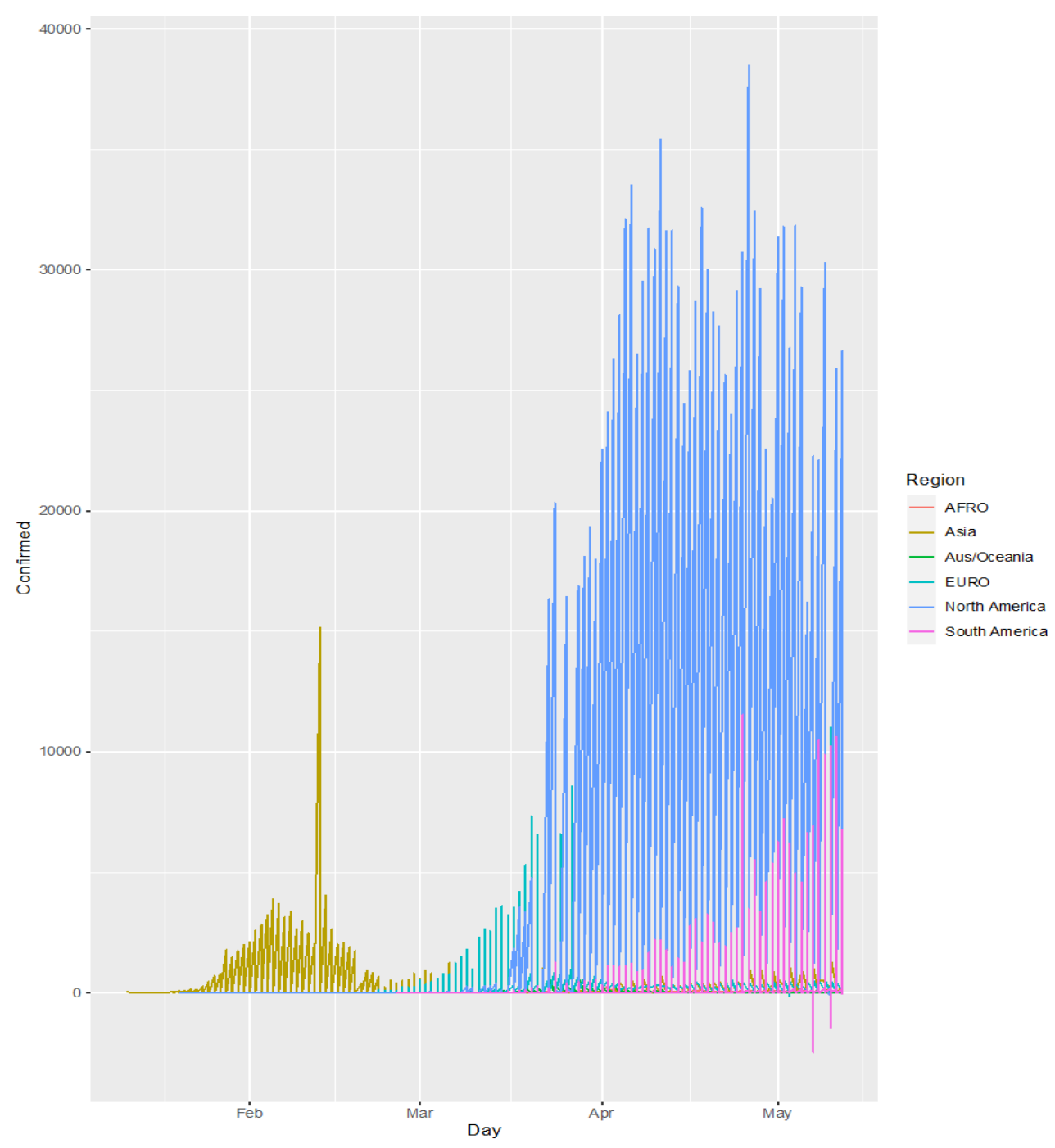

Fig. 2. Global simulation of COVID-19 confirmed cases by region.

Across America's continent, the available statistics reported the total number of the COVID confirmed cases at 14 million with overall mortality outcome of more than 508 000. Based on the current control measures and government intervention, evidence shows that the COVID is currently out of control in the continent as the pandemic moves beyond contact tracing to community distribution (WHO, 2020). The spatial distribution of the COVID in America's continent also reflected the overwhelming nature and shortcomings of the public health facilities. As it were, human life, which is measured or gauged as a human capital resource, is, unfortunately, being depleted and sacrificed to this pandemic. See the spatial spread and trends in Figs. 3-6. 


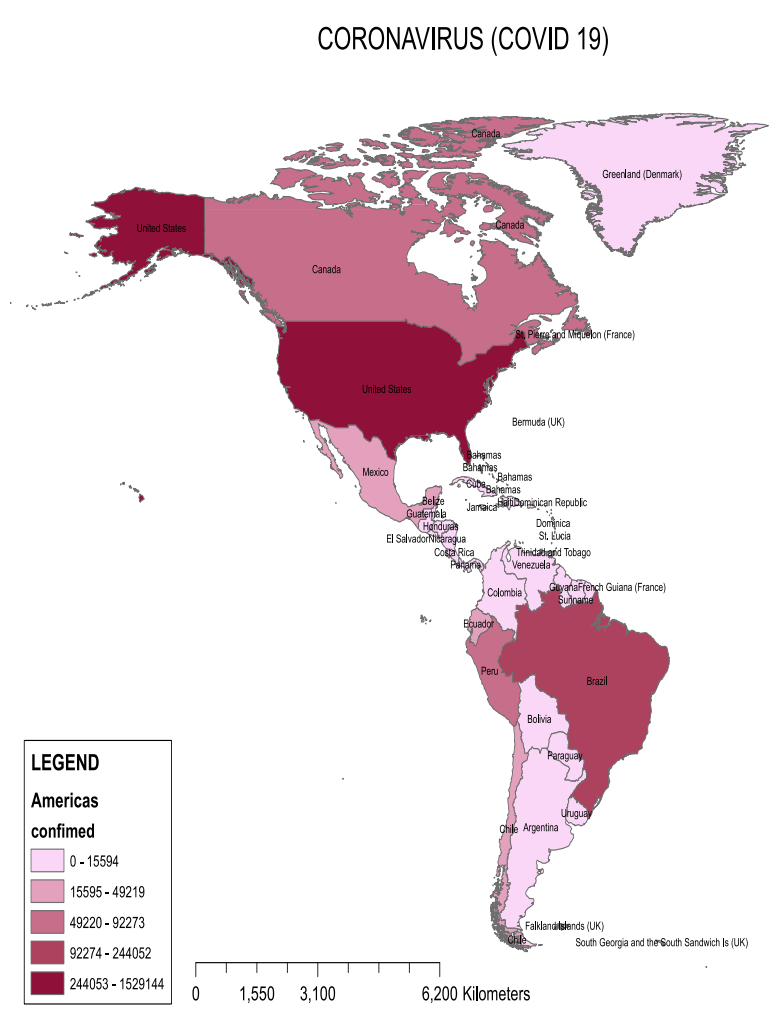

$\stackrel{N}{\Lambda}$

Fig. 3. Spatial distribution of confirmed cases in the Americas.

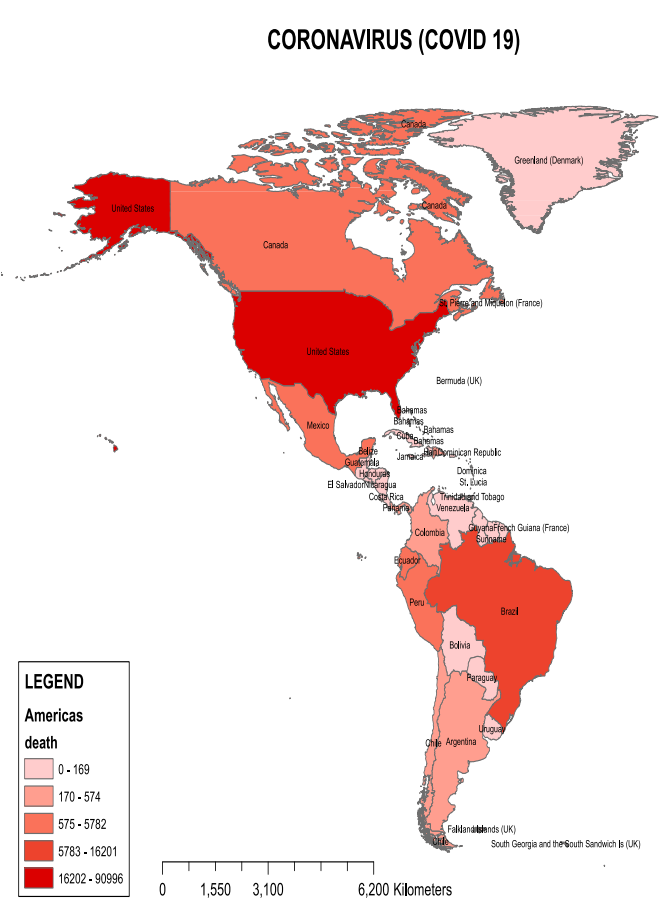

$\AA^{N}$

Fig. 4. Spatial distribution of COVID-19 mortality in the Americas. 


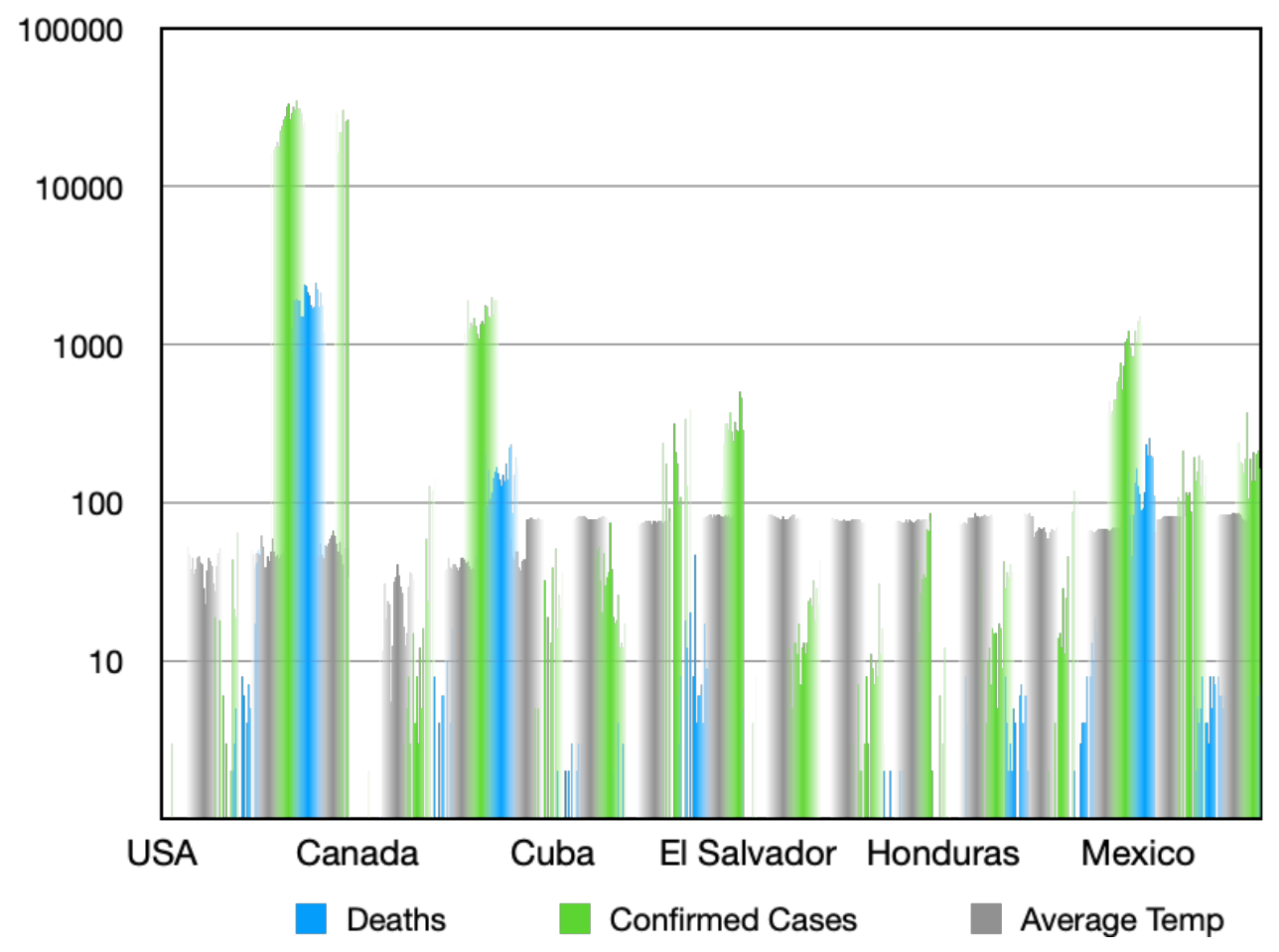

Fig. 5. Drivers of COVID-19 mortality in the North American region.

100000

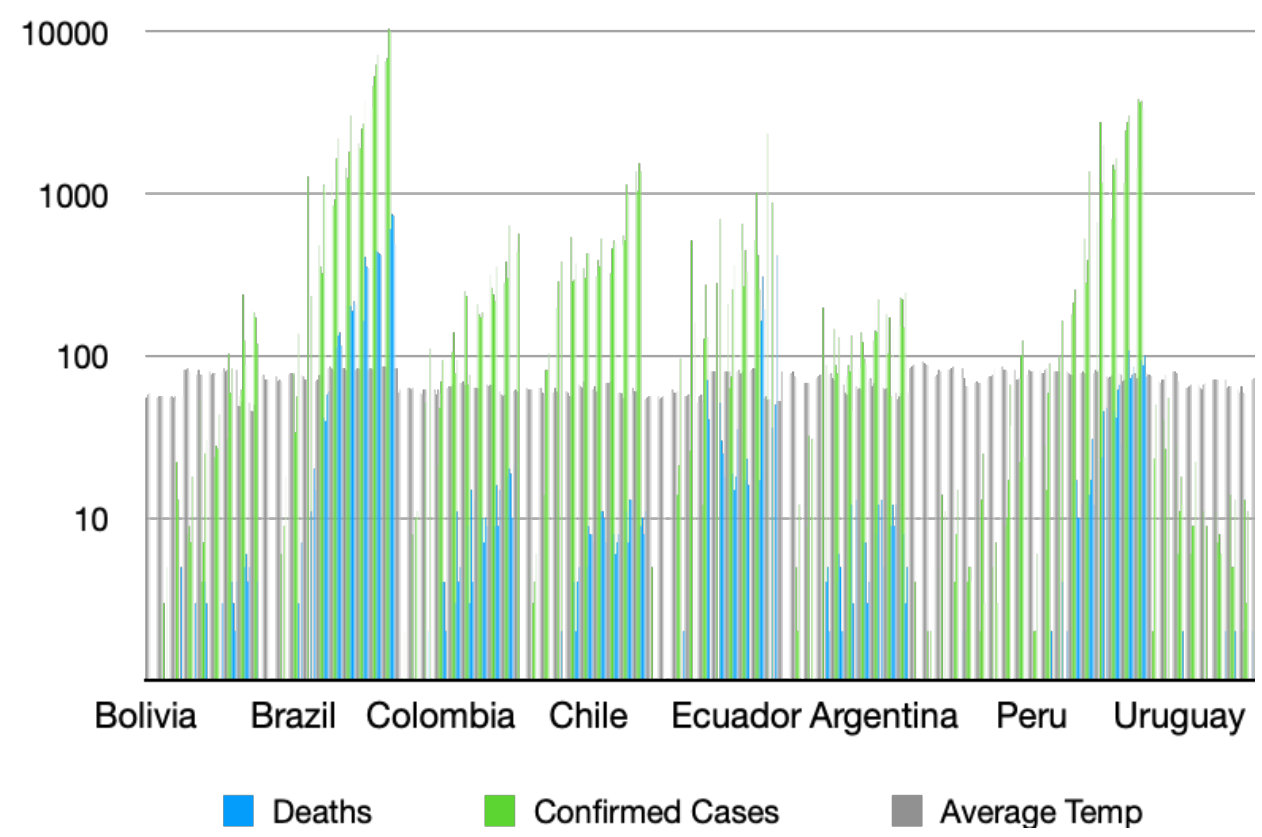

Fig. 6. Drivers of COVID-19 mortality in the South American region. 
Across the European continent, the available statistics reported the total number of the COVID confirmed cases at 4.7 million with overall mortality outcome of more than 225494 (WHO, 2020). The continent has adopted complete lockdown, physical distancing as well as contact tracing as a measure to contain the spread of the pandemics. Despite these efforts, progress is yet to be recorded as the COVID disease has shifted from mortality of old to the young generation. Many medical experts and scientists have been victims of the pandemic losing their lives. See the spatial spread and trends in Figs. 7-9.

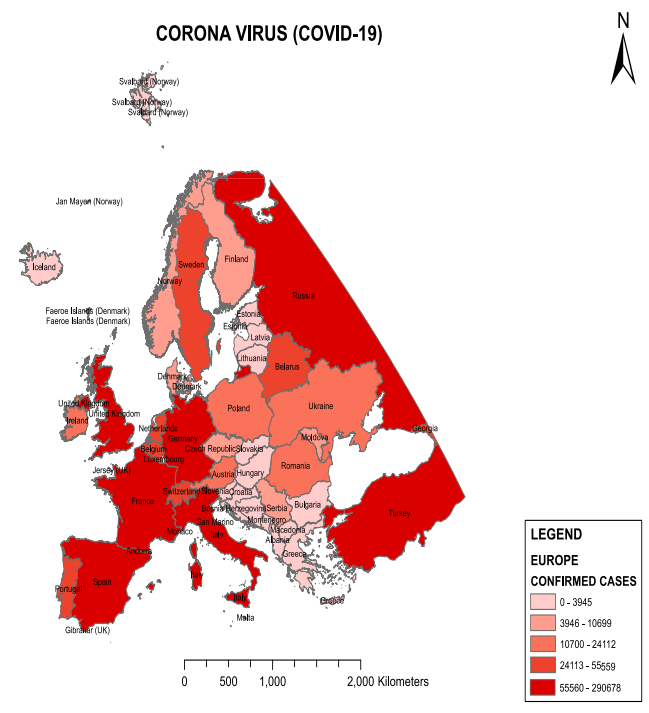

Fig. 7. Spatial distribution of confirmed cases in Europe.

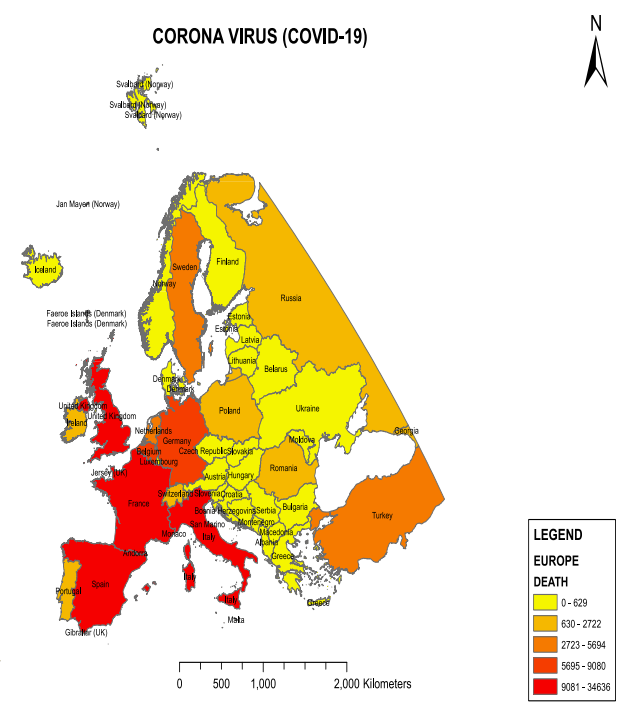

Fig. 8. Spatial distribution of COVID-19 mortality in Europe. 


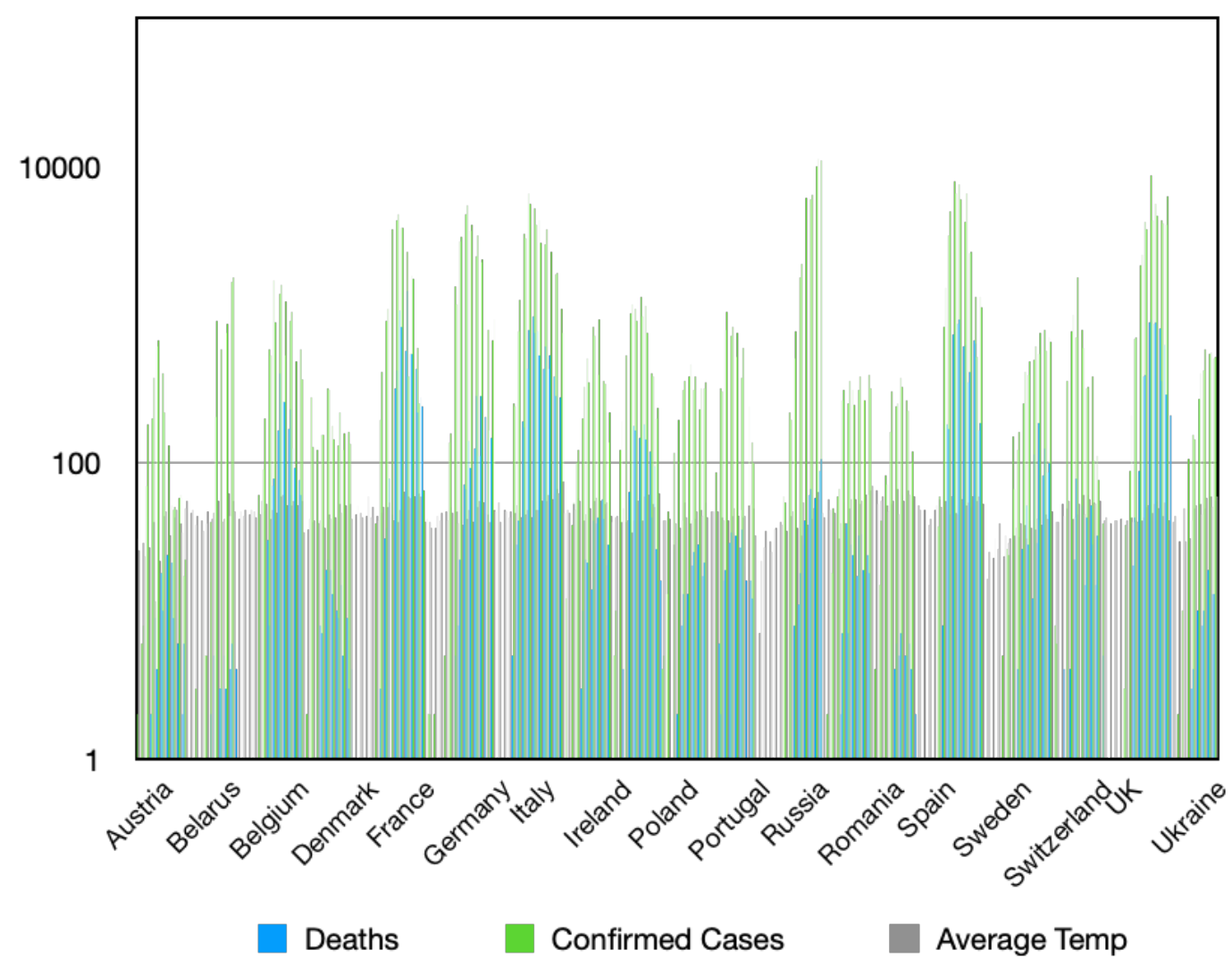

Fig. 9. Drivers of COVID-19 mortality in Europe.

In the Eastern Mediterranean region, the available statistics on the reported number of confirmed COVID disease cases is approximately put at 2 million with total mortality outcome of more than 55102 (WHO, 2020). The region has adopted complete lockdown, physical distancing as well as contact tracing to contain the spread of the pandemic. At the moment, intervention policies and efforts by authorities have contributed to reducing the infectious rate of the COVID disease spread at the first wave of the outbreak. However, epidemiologists have warned that the continent should reconsider the lockdown and social, physical distancing strategies as the outbreak of the second wave is expected through community transmission, which is likely to expose children, parents and medical staff to the disease beyond the public health capacity and the population at large.

In the Western Pacific region, the available statistics on the reported number of confirmed COVID disease cases is nearly 546552 with total mortality outcome of more than 11886 (WHO, 2020). The region has implemented a series of measures to contain the COVID spread ranging from physical distancing and contact tracing as well as improved healthcare supply. This reflects a slight decline in the number of cases, which is yet to be sustained. However, due to the quest for economic recovery, some of the countries have continued to ease the lockdown, which might have an effect on the second wave of the outbreak, if not carefully managed. See the trends in Fig. 10. 


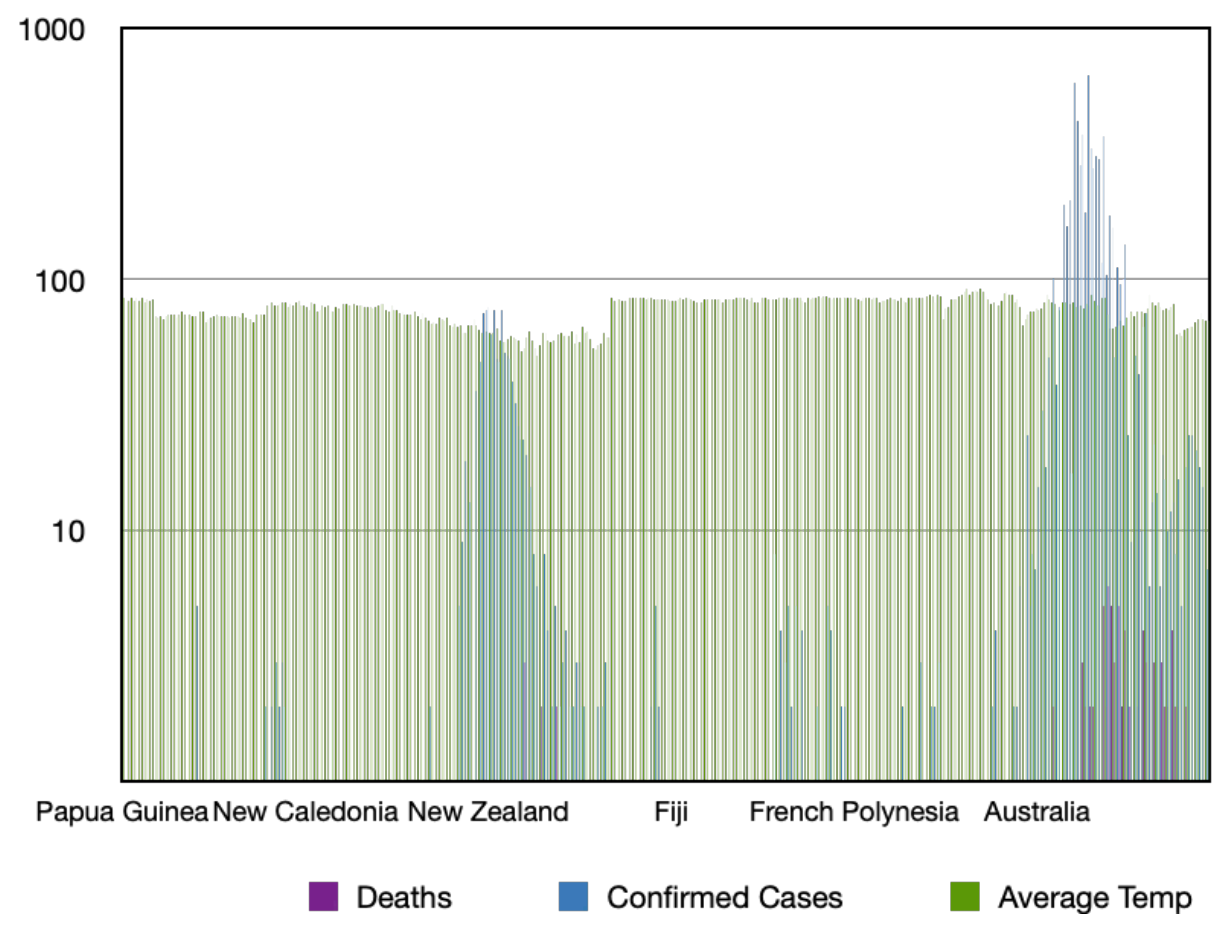

Fig. 10. Drivers of COVID-19 in the region of Australia/Oceania.

In Southeast Asia, the available statistics on the reported number of the confirmed COVID disease cases is nearly 5 million with a total mortality outcome of more than 92391 (WHO, 2020). The region has adopted a different measure to contain the COVID spread ranging from physical distancing, technological surveillance, and the extensive coverage of testing capacity combined with mobilisation of healthcare supply facility at the communities' level. This reflects the slight decline in the number of cases which is yet to be sustained (WHO, 2020). However, due to the quest for economic recovery, some of the countries have continued to ease the lockdown, which might have an effect on the second wave of the outbreak, if not carefully managed. See the spatial spread and trends in Fig. 11.

Across Africa, the available statistics on the reported number of the confirmed COVID disease cases is nearly 1.1 million with total mortality outcome of more than 23916 (WHO, 2020). The continent has adopted different measures to contain the spread of the disease ranging from physical distancing, lockdown, palliative distributions, contact tracing combined with mass testing at the community level. Despite these intervention strategies, it appears that a low level of education, inequality in the system, poor coordination, limited healthcare facilities and widening poverty gap have raised grave concern on the ability of the continent to manage successfully or survive the spatial distribution of the virus (WHO, 2020). This problem reflected the growing number of cases and mortality in the continent. WHO (2020) has warned that the African continent is likely to be the epicentre of the COVID disease spatial distribution with the capacity of the health system to cope with a significant concern to the international community. Also, the heightened level of social tension in the continent owing to a lack of basic amenities 
has continued to create a setback on the existing measured implemented. See the spatial spread and trends in Figs. 12-14.

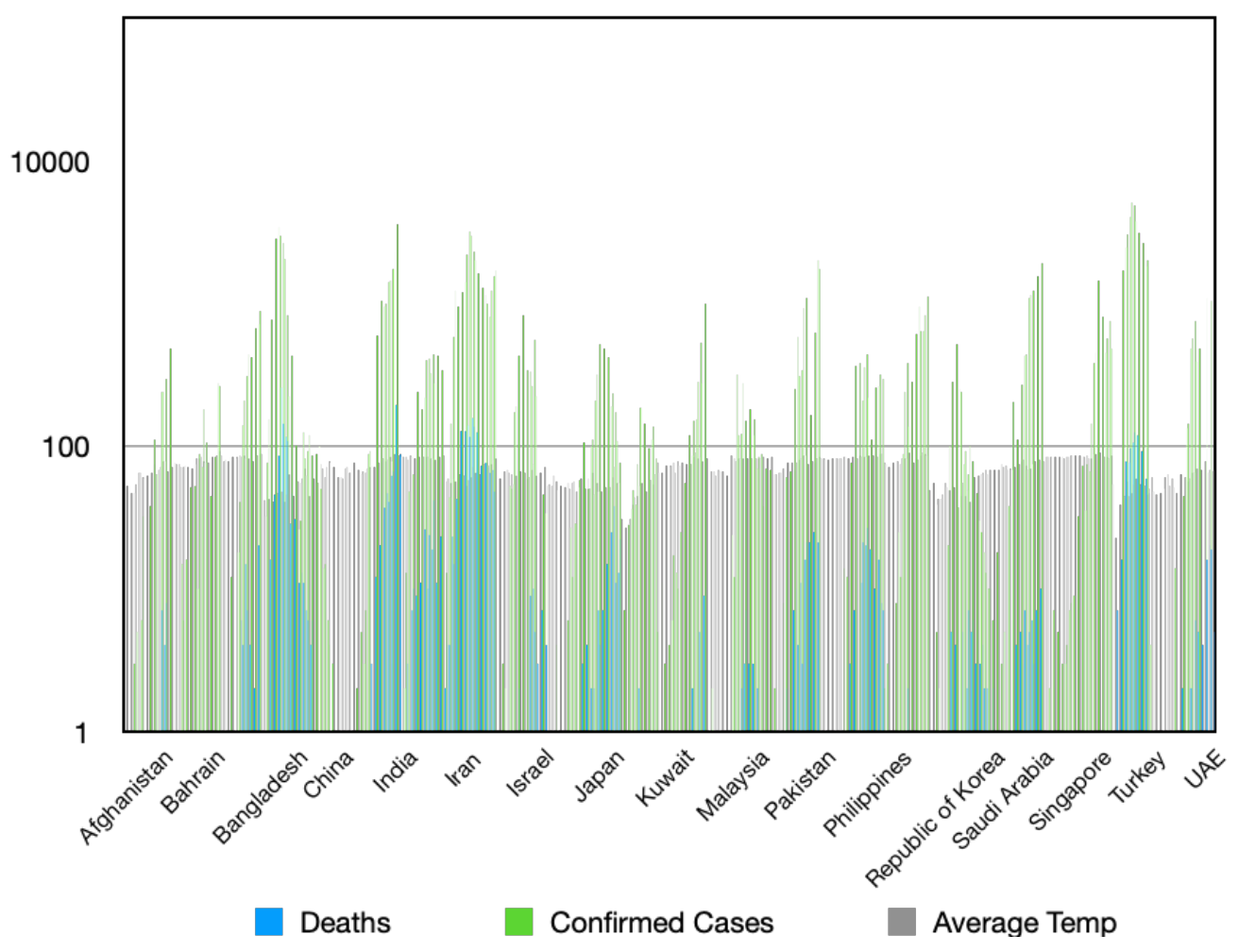

Fig. 11. Drivers of COVID-19 in Asia.

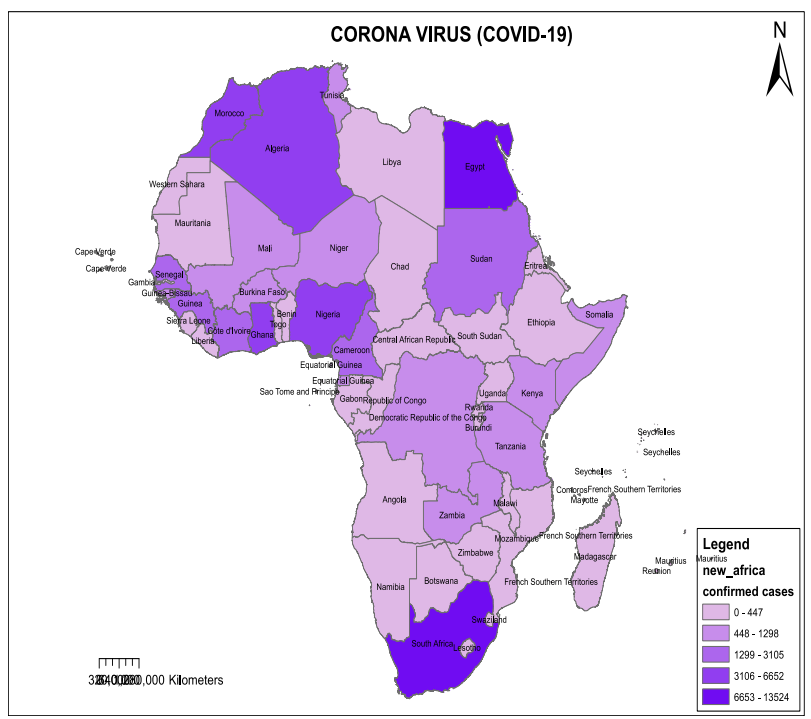

Fig. 12. Spatial distribution of confirmed cases in Africa. 


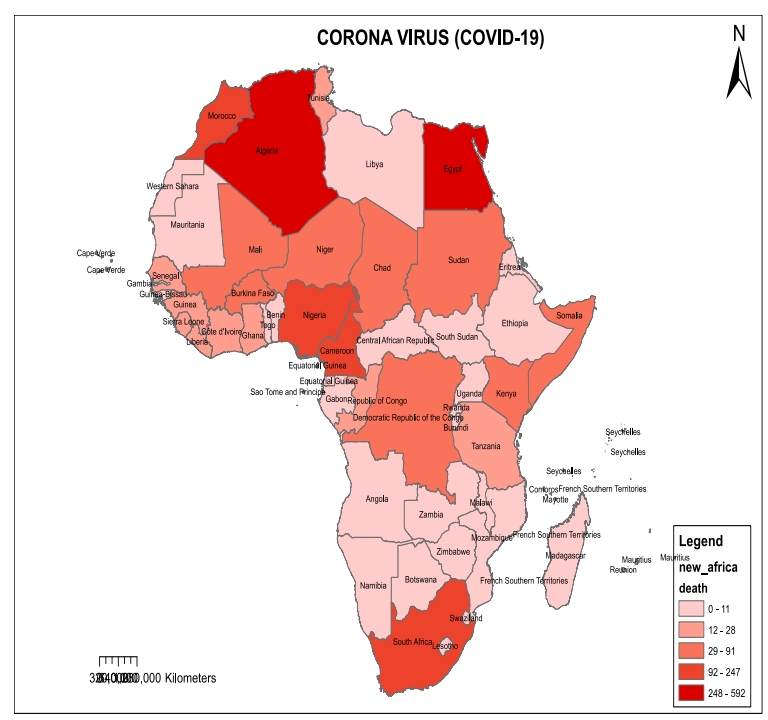

Fig. 13. Drivers of COVID-19 mortality in Africa.

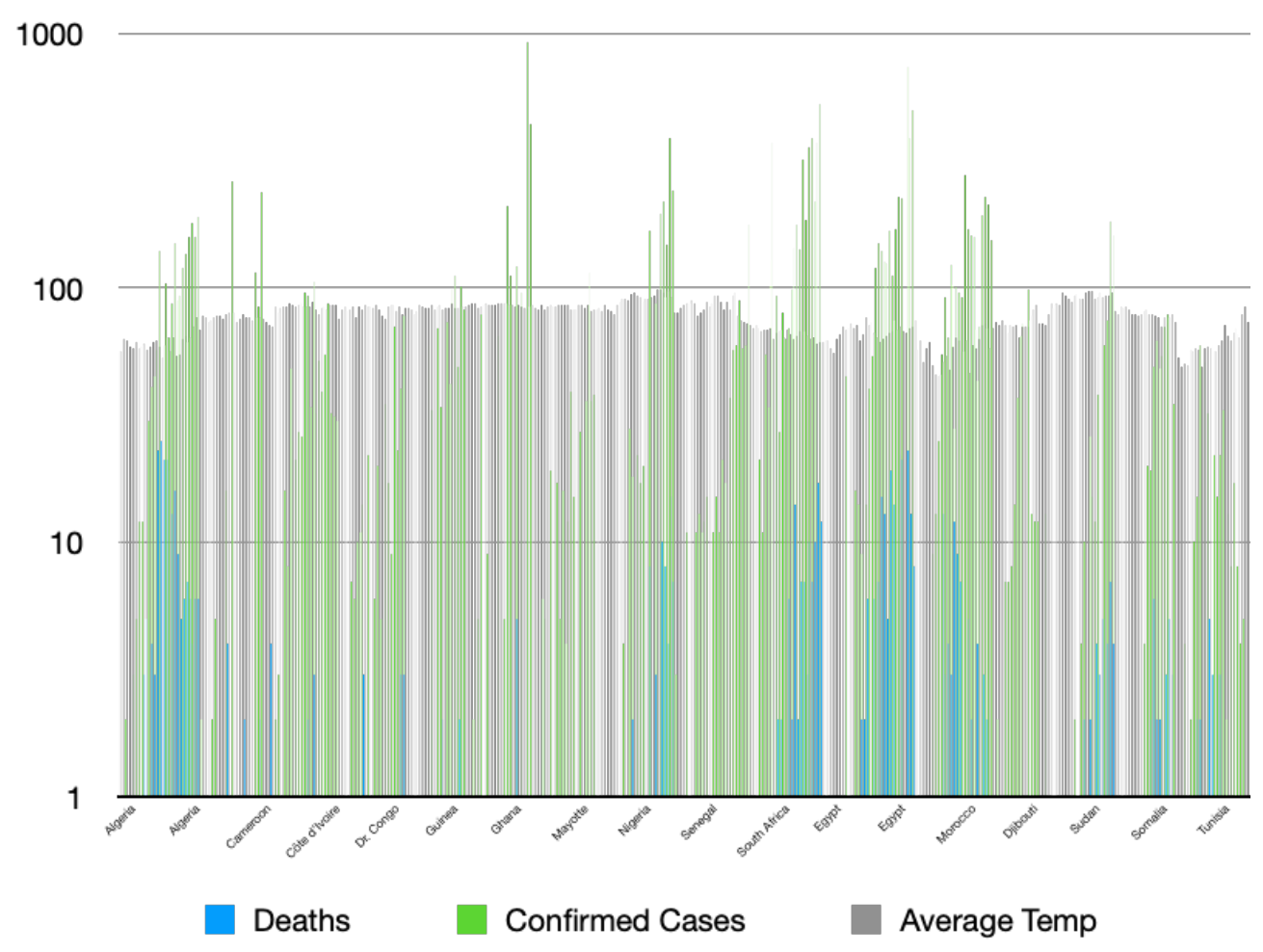

Fig. 14. Drivers of COVID-19 mortality in Africa. 


\section{BRIEF SURVEY OF LITERATURE}

On an intuitive level, the standard theory looking at the rationale on the varied approaches to control a pandemic is rooted in the Becker theory. The Grossman models have provided an elegant foundation for assessing the implication on the health outcome (Grossman, 1972; Rodgers, 1979). Based on the Grossman theoretical model, three potential propositions are presented in this paper:

\section{Effect of the spatial attribute on mortality outcomes}

The expansion of the link between spatial distribution and mortality outcomes has become the subject of immense debate among scientists. One major unsettled argument is whether an exponential increase in the novel coronavirus is associated with the mortality outcomes. Several studies on the effect of spatial distribution recorded conflicting results. For example, the study by Adekunle et al. (2020) examined the spatial variations of COVID disease on mortality outcomes using the Generalised Method of Moment (GMM) and reported strong evidence and connection with the number of confirmed cases and death rate in Algeria. However, findings were mixed in the rest of the countries studied. Contrariwise, Shereen and Siddique (2020) examined the origin of COVID infection with a specific focus on the nature of the transmission combined with the possibility of human attributes of the infectious spread and reported that existing relations exist on the possibility of human-to-human transmission in the spread of the COVID confirmed cases. Based on the existing studies, it is unclear whether spatial or human attribute accounts for the rising mortality outcomes. By this token, the following hypothesis has been formulated: Spatial attribute of COVID has a positive impact on mortality outcomes.

\section{Mediating the role of temperature variation}

It is widely acknowledged that temperature variation has a mediating link with mortality outcomes (Araujo \& Naimi, 2020). For example, earlier studies on the effect of temperature and the mechanism for the spread of coronavirus plus its influence on mortality outcomes concluded that the stability of human coronavirus $229 \mathrm{E}$ infectivity was maximum at PH 6.0 when incubated at either four or $33^{\circ} \mathrm{C}$ (Ma et al., 2020). Contrariwise, a recent study by Ahmadi et al. (2020) analysed the effect of temperature on the spread of COVID-19 outbreak in Iran and reported that average temperature, average precipitation, humidity, wind speed and average solar radiation were associated with the spread of COVID-19 disease in Iran. Using the Generalised Additive Model (GAM), Ma et al. (2020) explored the effect of humidity and diurnal temperature range on daily death count of COVID-19 in China and reported a positive and significant relation between COVID-19 death count and temperature variation. Other related studies investigating health effect of hot and cold temperature on mortality outcomes reported mixed evidence (Barreca, 2020; Gasparrini et al., 2015).

\section{Mediating the role of social tension}

The majority of the studies on public health widely accepted the perceived role of social tension on mortality outcomes (Shobande, 2019, 2020). Thus, mixed 
evidence was reported on the degree at which socioeconomic factors explained the risk of mortality outcome (Etienne, Skali \& Theodossious, 2011, Kawachi and Kennedy, 1997a, 1997b). Earlier studies by Mellor and Milyo (2002) found no evidence of such relating to health status. Contrariwise, a study by Etienne, Skali and Theodossiou (2011) reportedly found positive evidence in Europe. Equally, Shobande $(2019,2020)$ reported strong evidence on the positive and significant link between socioeconomic factors and mortality outcomes in Africa.

In the light of the literature surveyed above and potential propositions, the following can be deduced from existing literature - little consensus exists that COVID disease spread is exponential, but less agreement exists on the severe implication of this spread with regards to spatial variation. Also, whether temperature variation has a mediating effect on COVID spread and mortality remained unsettled in the existing literature. In addition, there is an ongoing debate on whether a social factor has a mediating effect on COVID spread and mortality outcomes. In terms of statistics flaws, the existing models used in testing the issue of serial correlation, omitted variable bias and endogeneity issues were far from existing results. As such, further extended models are required to provide more explanation on existing findings on the potential impact of COVID spread on mortality outcomes. In order to address the observed research gap, the present study provides a statistical model with an established econometric approach in closing the lacuna with strategies for addressing the present and potential future outbreak globally.

\section{METHODOLOGY AND DATA}

The section presents the research method that consists of model specification and data description and estimation method.

\section{Initial Model Specification}

The functional relationship between COVID spread and mortality outcome can be specified as follows:

$$
\text { Mortality }=f(\text { confcase, Avtemp, Z })
$$

where mortality is the dependent variable, ConfCase and AvTemp is the independent variable and $Z$ is the control variable, which consists of social tension.

Our baseline tests examine the spatial distribution of COVID on mortality outcomes. The empirical relationship can be specified as follows:

$$
\begin{aligned}
& \text { COVID }-19 \mathrm{MO}_{i, t}=\alpha+\beta C O V I D-19 \mathrm{MO}_{i, t-1}+ \\
& \gamma \text { AvTemp }_{i, t}+\text {-ConfCase }_{i, t}+\eta \text { SocTen }_{i, t}+\lambda+\epsilon_{i, t},
\end{aligned}
$$

where $i$ is countries $1,2, \ldots, 79, t$ is 20th February-May 2020. COVID-19MO is the mortality outcome as a result of COVID, AvTemp is the average temperature, 
ConfCase is the confirmed cases of COVID, SocTen is the social tension index, and $\lambda$ is country, region and time fixed effects. We begin our empirical analysis by estimating (1) using the Fixed Effects (FE) and Random Effects (RE) techniques.

We further assume that there is a correlation between the explanatory variables and the error term. To control for this endogeneity problem, as well as omitted variable bias, unobserved panel heterogeneity and measurement errors, we use the System Generalized Method of Moment (SGMM) (Blundell and Bond, 1998, 2020; Arellano \& Bover, 2000; Baltagi, Bun and Saratidis, 2015) which is a dynamic panel data estimator. Our dynamic panel model is specified as follows:

$$
\begin{aligned}
& \text { COVID }-19 \mathrm{MO}_{i, t}=\alpha+\beta C O V I D-19 M O_{i, t-1}+\gamma \text { AvTemp } p_{i, t} \\
& +\theta \text { ConfCase }_{i, t}+\eta \text { SocTen }_{i, t}+\mu_{i, t}
\end{aligned}
$$

where $\mu_{i, t}=\lambda+\epsilon_{i, t}$ is assumed to be independent and normally distributed with mean zero and constant variance $\sigma_{\mu}^{2}$, across a cross-section and over time.

\section{Data Description and Source}

The study uses a panel data set for 79 countries across six continents ${ }^{*}$. We select the countries in each continent based on the number of cases. For Africa and North America, countries with cumulative confirmed cases (CCC) of 1000 and above are selected; for South America, countries with CCC of 500 and above are selected; for Australia and Oceania, countries with CCC of above 50 are selected; for Europe and Asia, countries with CCC of 10,000 and more and 5000 and more are selected, respectively. Daily data for COVID deaths and confirmed cases are obtained from the World Health Organization (WHO) situation report. ${ }^{\dagger}$ We rely on the daily report of the maximum and minimum temperature from the NOAA National Centres for Environmental Information. ${ }^{\star}$ We compute the average temperature of the city with the most confirmed cases of COVID-19.

\section{EMPIRICAL RESULTS AND DISCUSSION}

The section presents the empirical results of our estimated model and discussion of the findings. Table 1 shows the results of the FE and RE estimator. In the estimation, we control for only the initial level of one-period lag COVID$19 \mathrm{MO}$. Both the random effect and fixed effect results are reported, and the decision on the appropriate technique is subject to the Hausman test. We obtain a positive

\footnotetext{
* Africa: South Africa, Egypt, Morocco, Algeria, Ghana, Nigeria, Cameron, Guinea, Senegal, Cote d'Ivoire, Sudan, Djibouti, Somalia, DR Congo, Mayotte and Tunisia.

North America: USA, Canada, Mexico, Dominican Rep., Panama, Honduras, Cuba, Guatemala, and El Salvador. South America: Brazil, Peru, Chile, Ecuador, Colombia, Argentina, Bolivia, Paraguay, and Uruguay.

Australia/Oceania: Australia, New Zealand, French Polynesia, Fiji, New Caledonia, and Papua New Guinea.

Europe: Spain, Russia, UK, Italy, France, Germany, Belgium, Netherland, Switzerland, Portugal, Sweden, Belarus, Ireland, Poland, Ukraine, Romania, Austria, Denmark, and Serbia.

Asia: Turkey, Iran, China, India, Saudi, Pakistan, Qatar, Singapore, UAE, Bangladesh, Japan, Israel, Indonesia, Philippine,

Kuwait, South Korea, Malaysia, Bahrain, Kazakhstan, and Afghanistan.

${ }^{\dagger}$ https://covid19.who.int

https://www.ncdc.noaa.gov/cdo-web/datatools/findstation
} 
coefficient for Conf Cases in columns 1 and 2, which implies that a unit increase in confirmed cases of COVID will result in about 0.03 increase in COVID mortality outcome. Hence, it is important that those infected with the virus should be properly isolated to prevent further spread of the virus, which will increase the COVID-19 mortality rate.

Table 1. Global Panel Fixed and Random Effect Results

\begin{tabular}{|c|c|c|c|c|c|c|}
\hline \multirow[b]{2}{*}{ Independent } & \multicolumn{6}{|c|}{ Dependent Variable: Covid19MO } \\
\hline & RE & FE & $\mathbf{R E}$ & FE & $\mathbf{R E}$ & FE \\
\hline ConfCase $_{i, t}$ & $\begin{array}{l}0.032 * * * \\
(0.001)\end{array}$ & $\begin{array}{l}0.034 * * * \\
(0.001)\end{array}$ & & & & \\
\hline AvTemp $p_{i, t}$ & & & $\begin{array}{l}-0.427 * * * \\
(0.107)\end{array}$ & $\begin{array}{l}-1.103^{* * *} \\
(0.263)\end{array}$ & & \\
\hline SocTen $_{i, t}$ & & & & & $\begin{array}{l}15.225^{* * *} \\
(1.509)\end{array}$ & $\begin{array}{l}10.026^{* * *} \\
(1.006)\end{array}$ \\
\hline Covid-19MO ${ }_{i, t-1}$ & $\begin{array}{l}0.454 * * * \\
(0.012)\end{array}$ & $\begin{array}{l}0.385^{* * * *} \\
(0.012)\end{array}$ & $\begin{array}{l}0.747 * * * \\
(0.009)\end{array}$ & $\begin{array}{l}0.644 * * * \\
(0.010)\end{array}$ & $\begin{array}{l}0.723 * * * \\
(0.009)\end{array}$ & $\begin{array}{l}0.649 * * * \\
(0.010)\end{array}$ \\
\hline Constant & $\begin{array}{l}4.274 * \\
(1.727)\end{array}$ & $\begin{array}{l}6.162 * * * \\
(1.727)\end{array}$ & $\begin{array}{l}39.490^{* * *} \\
(7.179)\end{array}$ & $\begin{array}{l}-53.924 * * \\
(16.892)\end{array}$ & $\begin{array}{l}-30.172^{* * *} \\
(4.561)\end{array}$ & $\begin{array}{l}16.518^{* * *} \\
(1.832)\end{array}$ \\
\hline $\begin{array}{l}\text { Number of } \\
\text { countries }\end{array}$ & 79 & 79 & 79 & 79 & 79 & 79 \\
\hline Number of Obs. & 6.113 & 6.113 & 6.113 & 6.113 & 6.113 & 6.113 \\
\hline$R^{2}$ & 0.6271 & 0.5030 & 0.5590 & 0.4216 & 0.5651 & 0.4199 \\
\hline Hausman Test & & & & 046 & & 019 \\
\hline
\end{tabular}

Notes: $* * * * *, *$ show statistical significance at $1 \%, 5 \%$ and $10 \%$ level, respectively. Robust standard errors are in brackets below coefficients. The probability values are reported for the Hausman test.

Source: Researchers' Computation

The average temperature and COVID-19 mortality outcome are negative and significant at $1 \%$ level in columns 3 and 4 . An increase in the average temperature by 1-degree Fahrenheit will bring about 1.1 decrease in COVID-19 mortality outcome. The social tension index has a positive and significant coefficient in columns 5 and 6, which implies that an increase in social tension tends to increase global mortality outcome from COVID-19. The positive coefficient of one-period lag COVID-19MO across all columns implies that its increase will result in an increase in the current mortality outcome.

The results from the Hausman test indicate that the results of the Fixed effect are more appropriate for interpretation.

In Table 2, we include all independent variables and control. Across all columns, the coefficients of ConfCase and one-period lag of COVID-19MO are positive and statistically significant. Without controlling for fixed effects in columns 1 and 2, the coefficients of average temperature are positive and significant. When we controlled for fixed effects in columns 3 and 4, AvTempnegative but insignificant-have the expected signs. Similarly, in columns 3 and 4, the coefficients of social tension are smaller when compared to those in Table 1. Also, although the coefficients are positive, they are statistically insignificant. 
Table 2. Global Panel Fixed and Random Effect Results

\begin{tabular}{|c|c|c|c|c|}
\hline & \multicolumn{4}{|c|}{ Dependent Variable: Covid19 Mortality Rate } \\
\hline & (1) & (2) & (3) & (4) \\
\hline Independent & $\mathbf{R E}$ & $\mathbf{F E}$ & $\mathbf{R E}$ & $\mathbf{F E}$ \\
\hline ConfCase $_{i, t}$ & $\begin{array}{l}0.031 * * * \\
(0.001)\end{array}$ & $\begin{array}{l}0.034 * * * \\
(0.001)\end{array}$ & $\begin{array}{l}0.033 * * * \\
(0.001)\end{array}$ & $\begin{array}{l}0.033 * * * \\
(0.001)\end{array}$ \\
\hline$A v T e m p_{i, t}$ & $\begin{array}{l}0.062 \\
(0.115)\end{array}$ & $\begin{array}{l}0.424 * \\
(0.245)\end{array}$ & $\begin{array}{l}-0.362 \\
(0.278)\end{array}$ & $\begin{array}{l}-0.362 \\
(0.276)\end{array}$ \\
\hline SocTen $_{i, t}$ & $\begin{array}{l}8.528^{* * *} \\
(1.645)\end{array}$ & $\begin{array}{l}5.894 * * * \\
(1.221)\end{array}$ & $\begin{array}{l}2.662 \\
(22.354)\end{array}$ & $\begin{array}{l}1.004 \\
(10.221)\end{array}$ \\
\hline Covid-19MO $\mathrm{O}_{i,-1}$ & $\begin{array}{l}0.447 * * * \\
(0.012)\end{array}$ & $\begin{array}{l}0.385^{* * *} \\
(0.012)\end{array}$ & $\begin{array}{l}0.377 * * * \\
(0.013)\end{array}$ & $\begin{array}{l}0.377 * * * \\
(0.013)\end{array}$ \\
\hline Constant & $\begin{array}{l}-23.080 * * \\
(10.639)\end{array}$ & $\begin{array}{l}-20.874 \\
(15.692)\end{array}$ & $\begin{array}{l}-2.235 \\
(135.056)\end{array}$ & $\begin{array}{l}13.045 \\
(129.736)\end{array}$ \\
\hline $\begin{array}{l}\text { Country } \\
\text { dummies }\end{array}$ & No & No & Yes & Yes \\
\hline Region dummies & No & No & Yes & Yes \\
\hline Day dummies & No & No & Yes & Yes \\
\hline $\begin{array}{l}\text { Number of } \\
\text { countries }\end{array}$ & 79 & 79 & 79 & 79 \\
\hline Number of Obs. & 6113 & 6113 & 6113 & 6113 \\
\hline$R^{2}$ & 0.6291 & 0.5032 & 0.6519 & 0.5137 \\
\hline Hausman Test & & & & \\
\hline
\end{tabular}

Notes: $* * * * *, *$ show statistical significance at $1 \%, 5 \%$ and $10 \%$ level, respectively. Robust standard errors are in brackets below coefficients. The probability values are reported for the Hausman test.

Source: Researchers' Computation

In empirical work, controlling for potential problem of endogeneity is crucial. Thus, we use the SGMM technique because it deals with both endogeneity and heteroscedasticity. For SGMM, we use the lag of the dependent variable as an independent variable and the lags of endogenous variables as instruments.

Table 3 presents the results based on SGMM. The focused variables of confirmed cases, social tension, and one-period lag of COVID-19MO are positive and statistically significant at the $1 \%$ significance level. An additional confirmed case of COVID-19 will bring about 0.031 increase in COVID-19 mortality outcome in the short run, ceteris paribus also, if the social tension index increases by one, mortality outcome in the short run will increase by about 9.78 , whereas an increase in the lag of COVID-19MO will increase current morality outcome by about 0.44 . On the other hand, the average temperature is negative and statistically insignificant. 
Table 3. Global System GMM One-Step Result

\begin{tabular}{|c|c|}
\hline \multicolumn{2}{|l|}{ Dependent Variable: COVID-19MO } \\
\hline Variable & Estimates \\
\hline ConfCase $_{i, t}$ & $\begin{array}{l}0.031 * * * \\
(0.005)\end{array}$ \\
\hline$A v T e m p p_{i, t}$ & $\begin{array}{l}-0.064 \\
(0.125)\end{array}$ \\
\hline SocTen $_{i, t}$ & $\begin{array}{l}9.779 * * * \\
(4.773)\end{array}$ \\
\hline Covid1-9MO $O_{i, t-1}$ & $\begin{array}{l}0.444 * * * \\
(0.012)\end{array}$ \\
\hline Constant & $\begin{array}{l}-37.180^{*} \\
(18.685)\end{array}$ \\
\hline Day dummies & Yes \\
\hline Number of countries & 79 \\
\hline Number of Obs. & 6113 \\
\hline \multicolumn{2}{|l|}{ Instrumental variable validation } \\
\hline$A R 1(\operatorname{Pr}>z)$ & 0.034 \\
\hline$A R 2(\operatorname{Pr}>z)$ & 0.182 \\
\hline \multicolumn{2}{|l|}{ Hansen Test for overriding restriction } \\
\hline Chi2 & 0.178 \\
\hline Prob $>$ Chi2 & 0.620 \\
\hline F Statistic & $\begin{array}{l}10460.82 \\
(0.000)\end{array}$ \\
\hline
\end{tabular}

Notes: ${ }^{* * *}, *$ show statistical significance at $1 \%$ and $10 \%$ level, respectively. Robust standard errors are in brackets below coefficients. Source: Researchers' Computation

The Hansen (1982) J-test is not significant at $5 \%$, which implies that our instrument set is good, as we fail to reject the null of overidentifying restriction. The second-order serial correlation result (AR2) indicates that there is no serial correlation. The F-statistics value indicates that the model is joint statistically significant at the $5 \%$ level of significance.

Table 4 presents the group estimates of the countries according to their region and they are estimated using the SGMM. We find that in Africa, confirmed cases and the one-period lag of COVID-19MO have a positive and significant impact on current COVID-19 mortality outcome in the short run. Social tension index for Africa continent, although it is insignificant, is the smallest when compared to other columns. This might be as a result of a low number of cases reported in this continent. On the other hand, the average temperature has a negative impact on COIVD-19 mortality outcome, although it is statistically insignificant. 
Table 4. Regional Panel System GMM One-Step Result. Dependent Variable: COVID19MO

\begin{tabular}{|c|c|c|c|c|c|c|}
\hline Variable & Africa & $\begin{array}{l}\text { North } \\
\text { America }\end{array}$ & $\begin{array}{l}\text { South } \\
\text { America }\end{array}$ & $\begin{array}{l}\text { Australia/ } \\
\text { Oceania }\end{array}$ & Asia & Europe \\
\hline ConfCase $_{i, t}$ & $\begin{array}{l}0.021 * * * \\
(0.006)\end{array}$ & $\begin{array}{l}0.039 * * * \\
(0.006)\end{array}$ & $\begin{array}{l}0.023 * * * \\
(0.011)\end{array}$ & $\begin{array}{l}0.002 * * * \\
(0.0001)\end{array}$ & $\begin{array}{l}0.012 * * * \\
(0.003)\end{array}$ & $\begin{array}{l}0.048^{* *} \\
(0.009)\end{array}$ \\
\hline$A v T e m p_{i, t}$ & $\begin{array}{l}-0.053 \\
(0.031)\end{array}$ & $\begin{array}{l}-0.184 \\
(0.793)\end{array}$ & $\begin{array}{l}0.158 \\
(0.181)\end{array}$ & $\begin{array}{l}-0.011^{* * *} \\
(0.003)\end{array}$ & $\begin{array}{l}-0.005 \\
(0.106)\end{array}$ & $\begin{array}{l}1.816 \\
(1.445)\end{array}$ \\
\hline SocTen $_{i, t}$ & $\begin{array}{l}0.007 \\
(0.458)\end{array}$ & $\begin{array}{l}18.562 \\
(14.975)\end{array}$ & $\begin{array}{l}1.804 \\
(3.007)\end{array}$ & $\begin{array}{l}0.799 * * * \\
(0.094)\end{array}$ & $\begin{array}{l}11.754^{* *} \\
(4.298)\end{array}$ & $\begin{array}{l}48.705 * * * \\
(13.041)\end{array}$ \\
\hline Covid-19MO $_{i, t-1}$ & $\begin{array}{l}0.203^{*} \\
(0.099)\end{array}$ & $\begin{array}{l}0.269 * * * \\
(0.011)\end{array}$ & $\begin{array}{l}0.587 * * * \\
(0.064)\end{array}$ & $\begin{array}{l}0.292 * * \\
(0.113)\end{array}$ & $\begin{array}{l}0.004 * * \\
(0.002)\end{array}$ & $\begin{array}{l}0.130^{*} \\
(0.074)\end{array}$ \\
\hline Constant & $\begin{array}{l}3.270 \\
(2.307)\end{array}$ & $\begin{array}{l}-87.949 \\
(80.901)\end{array}$ & $\begin{array}{l}-20.236 \\
(25.383)\end{array}$ & $\begin{array}{l}-0.808 \\
(0.210)\end{array}$ & $\begin{array}{l}-42.014^{* * *} \\
(18.786)\end{array}$ & $\begin{array}{l}-69.365^{* *} \\
(8.396)\end{array}$ \\
\hline Day dummies & Yes & Yes & Yes & Yes & Yes & Yes \\
\hline Number of countries & 16 & 9 & 9 & 6 & 20 & 19 \\
\hline Number of Obs. & 1056 & 661 & 607 & 404 & 1758 & 1626 \\
\hline \multicolumn{7}{|l|}{$\begin{array}{l}\text { Instrumental variable } \\
\text { validation }\end{array}$} \\
\hline$A R 1(P r>z)$ & 0.026 & 0.058 & 0.095 & 0.064 & 0.026 & 0.034 \\
\hline$A R 2(\operatorname{Pr}>z)$ & 0.264 & 0.260 & 0.113 & 0.597 & 0.800 & 0.182 \\
\hline \multicolumn{7}{|l|}{ Hansen Test } \\
\hline Chi2 & 0.128 & 0.109 & 0.118 & 0.221 & 0.228 & 0.178 \\
\hline Prob $>$ Chi2 & 0.469 & 0.454 & 0.221 & 0.469 & 0.569 & 0.620 \\
\hline F-Statistic & $\begin{array}{l}6430.39 \\
(0.000)\end{array}$ & $\begin{array}{l}2309.34 \\
(0.000)\end{array}$ & $\begin{array}{l}130.39 \\
(0.043)\end{array}$ & $\begin{array}{l}40.09 \\
(0.000)\end{array}$ & $\begin{array}{l}9.07 \\
(0.000)\end{array}$ & $\begin{array}{l}33.54 \\
(0.000)\end{array}$ \\
\hline
\end{tabular}

Notes: ***,**,* show statistical significance at $1 \%, 5 \%$ and $10 \%$ level, respectively. Robust standard errors are in brackets below coefficients

Source: Researchers' Computation

In column 2, Table 4, the results for North America show that in terms of magnitude, confirmed cases are positive and significant. This implies that a unit increase in the confirmed case of COVID-19 will result in about 0.04 increase in the mortality outcome. In terms of magnitude, confirmed cases for North America are the second largest when compared to other columns. Also, a one-period lag of COVID-19MO has a positive short-run impact on a mortality rate, such that a single death attributed to COVID-19 in the last period will bring about 0.3 increase in the mortality outcome in the current period. On the other hand, social tension has a positive but insignificant impact on the mortality outcome, with the second-largest coefficient when compared with another region.

The results for South America are reported in column 3, Table 4. A unit increase in confirmed cases and one-period lag of COIVD-19MO will bring about an approximate increase in the current mortality outcome by 0.023 and 0.587 , respectively. Coefficients for social tension and average temperature remain statistically insignificant. 
In column 4, Table 4, we present the results for Australia/Oceania. The coefficient of confirmed cases in this region is positive and significant such that an additional case will result in a 0.002 death from COVID-19. The magnitude of the confirmed case is the smallest when compared to other regions in the other columns, which might be due to a population size of the region and their approach in curtailing the spread of the virus. Also, coefficients of social tension and one-period lag of COVID-19MO have a positive and significant impact on mortality outcomes from COVID-19 in the short run. However, an increase in the average temperature will reduce the mortality outcome of COVID-19 by about 0.01 in the short run. With fast winter approaching in this region, it will be important for the countries in this region to ensure all measures to flatten the curve and spread of the virus.

For Asia (see column 5, Table 4), we noticed that although the coefficient of a one-period lag of COVID-19 is positive and statistically significant, the magnitude is the smallest across all columns. This result is intuitive as most countries in the region have recorded a flatter curve for the number of cases and death resulting from COVID-19 in recent days. Coefficients for confirmed cases and one-period lag of COVID-19MO remain positive and statistically significant, whereas the average temperature is negative and insignificant.

The final column in Table 4 reports the results for Europe. The magnitude of the coefficient of confirmed cases and social tension index appear to be the largest across all region. A unit increase in these coefficients will lead to an increase in the current mortality outcome from COVID-19 by about 0.05 and 48.7, respectively. While in the last period mortality outcome has a positive impact on the current mortality outcome from COVID-19, the average temperature is positive and statistically insignificant.

Across all columns, the Hansen test indicates that we fail to reject the null of over-identifying restriction; the second-order serial correlation results (AR2) indicate that there is no serial correlation. The F-statistics value indicates that the model is joint statistically significant at the $5 \%$ level of significance.

\section{CONCLUSION}

The present study has extended extant literature on public health crises and its potential outcome on population health. The theoretic appeal of the Becker theory and Grossman Model (1972) is applied to examine the correlate of spatial attributes of COVID-19 spread on mortality outcome across the regions of the world. The sample of 79 countries selected across the regions of the world for the period of February-May 2020 has been considered. The evidence of this study is based on the FE and SGMM estimation methods. The predicted variable is proxy with daily mortality outcomes, while predictor variables are proxy with spatial COVID-19 spread while controlling for temperature and social tension. The findings of the study established the evidence of spatial variation in COVID-19 spread with positive and significant relations with mortality outcomes. Thus, the model suggests that strategies for containing the virus are likely to vary due to geographical location and circumstance of a public health framework. Further empirical results on temperature variation as a mediating effect on COVID-19 spread and mortality 
outcomes indicate that temperature variation is a key environmental driver of the COVID-19 spread. Therefore, this suggests that hot, cold or the warmth of the region are associated with the spread of the COVID-19 disease. Similarly, we found strong evidence on the positive and significant relations of a social factor as a mediating element on COVID-19 spread and mortality outcomes.

Many potential solutions arise from the outcome of the results of the model. First, the empirical results suggest that stakeholders must rely on the power of statistical prediction in planning for containing the present and preventing a potential future outbreak. Second, based on the prediction of our model, there is an urgent need to address the socioeconomic gap among regions of the world in order to enable and empower governments to contain the spread of the pandemic. Third, the issues of limited public health facilities and basic socioeconomic needs such as food, electricity and water resources needed to ensure environmental cleanliness and basic survival should be put in place. In addition, proactive research collaboration and coordination among scientists, virologists and medical experts need to be encouraged to curb the pandemic and reduce social tension. The international communities need to encourage peace, reconcile existing coordination failure among stakeholders while the media must trade with caution.

Our study supports the earlier work of Adekunle et al. (2020), Shobande (2020), Petra and Nigel (2020), Adekunle et al. (2020), Ma et al. (2020), but refutes the earlier work of Mellor and Milyo (2002). For future research, the effort can be focused on such areas as the effect of economic impacts, COVID19 spread and mortality outcomes. Such studies can provide further strategies on present and future control mechanism/strategies for a disease outbreak in the world.

\section{REFERENCES}

Adekunle, I. A., et al. (2020). Modelling spatial variations of coronavirus disease (COVID-19) in Africa. Science of The Total Environment, 729, 138998. https://doi.org/10.1016/j.scitotenv.2020.138998

Ahmadi, A., Fadaei, Y., Shirani, M., Rahmani, F. (2020). Modelling and forecasting trend of COVID19 epidemic in Iran. MedRxiv. https://doi.org/10.1101/2020.03.17.20037671

Araujo, M. B., \& Naimi, B. (2020). Spread of SARS-CoV-2 Coronavirus likely to be constrained by climate. MedRxiv. https://doi.org/10.1101/2020.03.12.20034728

Arellano, M., \& Bover, O. (1995). Another look at the instrumental variable estimation of error components models. J. Econ., 68(1), 29-51. https://doi.org./10.1016/0304-4076(94)01642-D.

Bun, M. J. G, \& Sarafidis, V. (2015). Dynamic panel data model. The Oxford Handbook of Panel Data. (Eds.) Badi H. Baltagi. [Online] https://doi.org/10.1093/oxfordhb/9780199940042.013.0003

Barreca, A. I. (2020). Climate change, humidity, and mortality in the United States. J. Environ Econ Manag. 63(1), 19-34. https://doi.org/10.1016/j.jeem.2011.07.004

Blundell, R., \& Bond, S. (1998). Initial conditions and moment restrictions in dynamic panel data models. J. Econ. 87(1), 115-143. https://doi.org/10.1016/s0304-4076(98)0009-8.

Blundell, R., \& Bond, S. (2000). GMM estimation with persistent panel data; an application to production functions. Econ. Rev. 19(3), 321-340. https://doi.org/10.1080/07474900088475.

Etienne, J., Skalli, A., \& Theodossious, I. (2020). Do inequalities harm health? Evidence from Europe. Journal of Income Distribution, 20(3-4), 57-74.

Gasparrini, A., et al. (2015). Mortality risk attributable to high and low ambient temperature: a multicountry observational study. The Lancet, 386(9991), 369-375.

https://doi.org/10.1016/S0140-6736(14)62114-0 
Gautam, S., \& Hens, L. (2020). SARS-CoV-2 pandemic in India: what might we expect? Environ Dev Sustain, 22, 3867-3869. https://doi.org/10.1007/s10668-020-00739-5

Grossman, M. (1972). On the concept of health capital and the demand for health. Journal of Political Economy, 80(2), 223-255. https://doi.org/10.1086/259880

Hansen, L. P. (1982). Large sample properties of the generalised method of moments estimators. Econometrica, 50(4), 1029-1054. https://doi.org/10.2307/1912775.

Kawachi, I., \& Kennedy, B. P. (1997a). Socioeconomic determinants of health: Health and social cohesion: Why care about income inequality? British Medical Journal, 314, 1037-1040. https://doi.org/10.1136/bmj.314.7086.1037

Kawachi, I., Kennedy, B. P., K. Lochner, K., \& Prothrow-Stith., D. (1997b). Social capital, income inequality and mortality. American Journal of Public Health, 87, 1491-1498. https://doi.org/10.2105/AJPH.87.9.1491

Ma, Y., et al. (2020). Effects of temperature variation and humidity on the death of COVID-19 in Wuhan, China. Science of The Total Environment, 724, 138226. https://doi.org/10.1016/j.scitotenv.2020.138226

Mellor, J. M., \& Milyo, D. (2002). Income inequality and health status in the United States: Evidence from the current population survey. Journal of Human Resources, 37(3), 510-539. https://doi.org/10.2307/3069680

Petra, Z., \& Nigel, C. (2020). Coronavirus infections in children, including COVID-19. The Pediatric Infectious Disease Journal, March 12, 2020. https://doi.org/10.1097/INF.0000000000002660

Rodgers, G. B. (1979). Income and inequality as determinants of mortality: an international crosssection analysis. Population Studies, 33, 343-51. https://doi.org/10.1080/00324728.1979.10410449

Sarkodie, S. A., \& Owusu, P. A. (2020). Investigating the cases of novel coronavirus disease (COV19) in China using statistical techniques. Heliyon 6(4), 03747. https://doi.org/10.1016/j.heliyon.2020.e03747.

Shereen, M.A., Khan, S., Kazmi, A., \& Siddique, R. (2020). COVID-19 infection: Origin, transmission, and characteristics of human coronavirus. J. Adv. Res. 24, 91-98. https://doi.org/10.1016/j.jare.2020.03.005.

Shobande, O. A. (2019). Effects of Energy Use on Socioeconomic Predictors in Africa: Synthesizing Evidence. Studia Universitatis „Vasile Goldis” Arad - Economics Series, 29(4), 21-40. https://doi.org/10.2478/sues-2019-0016

Shobande, O. A. (2020). Effects of energy use on the mortality rate in Africa. Environmental and Sustainability Indicators, 5, 100015, 1-11. https://doi.org/10.1016/j.indic.2019.100015.

WHO (2020). Coronavirus Disease 2019 (COVID-19) Situation Reports. World Health Organisation.

Yeo, C., Kaushal, S., Yeo, D. (2020). Enteric involvement of coronaviruses: Is facial oral transmission of SARS-CoV-2 possible? The Lancet Gastroenterol. Hepatol. 5(4), 335-337. https://doi.org/10.1016/s2468-1253(20)30048-0.

\section{AUTHORS' SHORT BIOGRAPHIES}

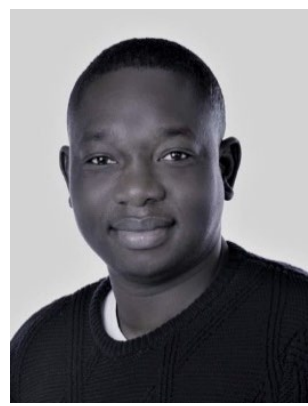

Olatunji Abdul Shobande is an Associate Researcher at the Business School of the University of Aberdeen, United Kingdom. His research aims at improving the lives of underserved individuals, placing priority around health, financial inclusion, and electricity access disparities while using a health promotion standpoint as a mechanism to implement incremental and impactful social, environmental and policy change. His research works have been published in many leading academic journals, such as the Review of Economies, Review of Urban \& Regional Studies, Science of Total Environment, Environmental and Sustainable Indicator, Review of Economic (MDPI), Business and Economics.

E-mail: Olatunji.shobande@abdn.ac.uk ORCID ID: https://orcid.org/0000-0003-4528-1857 


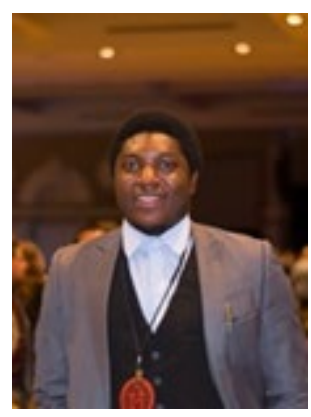

Lawrence Ogbeifun is a $\mathrm{PhD}$ Candidate of Economics at the University of Mississippi, USA. Previously, Lawrence obtained his Bachelor degree in Mathematics and Economics from the University of Benin and Distinction in MSc in Economics from the University of Lagos. His areas of research are macroeconomics, labour economics, monetary economics and environmental economics.

Email: logbeifu@go.olemiss.edu

ORCID iD: https://orcid.org/0000-0001-9249-6151 